\section{HTLV-1 infections}

Charles R M Bangham

\begin{abstract}
Human $T$ lymphotropic virus type 1 (HTLV-1) causes disabling and fatal diseases, yet there is no vaccine, no satisfactory treatment, and no means of assessing the risk of disease or prognosis in infected people. Recent research on the molecular virology and immunology of HTLV-1 shows the importance of the host's immune response in reducing the risk of these diseases, and is beginning to explain why some HTLV-1 infected people develop serious illnesses whereas most remain healthy life long carriers of the virus. These findings might be applicable to other persistent virus infections such as human immunodeficiency virus, hepatitis $B$, and hepatitis $C$. (f Clin Pathol 2000;53:581-586)
\end{abstract}

Keywords: human $\mathrm{T}$ lymphotropic virus type 1; adult T cell leukaemia/lymphoma; tropical spastic paraparesis; myelopathy

The human $\mathrm{T}$ lymphotropic virus type 1 (HTLV-1) is estimated to infect between 10 and 20 million people world wide. ${ }^{1}$ The virus causes at least two types of disease: a highly aggressive $\mathrm{T}$ cell malignancy, adult $\mathrm{T}$ cell leukaemia/lymphoma (ATL), and a variety of chronic inflammatory syndromes, most notably HTLV-1 associated myelopathy, which is also known as tropical spastic paraparesis (HAM/TSP). These syndromes are important causes of mortality and morbidity in the areas where HTLV-1 is endemic (see below). For example, in southern Japan, ATL is the most common form of non-Hodgkin's lymphoma. There is neither a vaccine against the virus, nor a satisfactory treatment for the malignancy or the inflammatory syndromes. However, there has been recent progress in the immunology, immunogenetics, and molecular virology of HTLV-1. This new information is beginning to suggest pathogenic mechanisms of the diseases. A full understanding of how the immune system reaches a dynamic equilibrium with the persistently replicating virus also casts light on many other persistent virus infections, such as human immunodeficiency virus (HIV), hepatitis B, and hepatitis C.

Department of Immunology, Imperial

College School of Medicine, St Mary's Campus, London W2 1PG, UK

C R M Bangham

Correspondence to: Professor Bangham email: c.bangham@ic.ac.uk

Accepted for publication 13 December 1999 populations of northern Australia, and many islands in the tropics. In Europe and North
America, the virus is found chiefly in certain immigrant groups and in intravenous drug users. Within the endemic areas, the distribution of HTLV-1 is typically uneven: the seroprevalence varies widely, between $0.1 \%$ and $30 \%$ of adults, often with great differences between neighbouring towns. There is an unexplained predilection for coastal areas.

The dominant modes of transmission of HTLV-1 in endemic areas are from mother to child in breast milk, and sexual transmission in adults; male to female transmission is about four times as frequent as female to male transmission. ${ }^{3}$ However, transmission by infected blood products has been a major problem in endemic regions, especially in Japan. ${ }^{45}$ Blood for transfusion is now screened routinely for HTLV-1 in several countries, including Japan, the USA, and Brazil. In Japan, screening of blood products and counselling on breast feeding has been followed by the beginning of a downward trend in the age dependent seroprevalence of HTLV $-1 .{ }^{67}$

The diagnosis of HTLV-1 infection is based on the detection of specific antibodies by particle agglutination or enzyme linked immunosorbent assays, and subsequent confirmation either by the polymerase chain reaction (PCR) or western blot assays. ${ }^{8}$ The most specific serological assay is the western blot, in which the antigen is a mixture of whole virus lysate with recombinant viral envelope proteins from either HTLV-1 or the closely related virus HTLV-2, which has not been convincingly associated with disease. The identity of the virus can be confirmed by $\mathrm{PCR}^{9}$; PCR is especially useful in cases where the western blot is indeterminate.

\section{The virus}

HTLV-1 was first isolated and identified ${ }^{10}$ from a patient with a cutaneous $T$ cell malignancy. Similarities in the clinical picture and the abnormal $\mathrm{T}$ cell morphology led to the suggestion that HTLV-1 was also involved in ATL, which had been described in Japan a few years earlier. ${ }^{11}$ Subsequent seroepidemiological and molecular work confirmed this connection..$^{10}{ }^{12-16}$

HTLV-1 is a complex type C retrovirus, in the subfamily Oncovirinae. ${ }^{17}$ Like other retroviruses, it has an envelope derived from the host cell membrane, and two copies of the positive sense RNA genome. The genome of 9032 nucleotides contains the gag, pol, and env genes found in replication competent exogenous retroviruses. In addition, HTLV-1 encodes two non-structural, regulatory proteins: Tax, the transcriptional transactivator of the virus, and Rex, the regulator of viral mRNA splicing. ${ }^{17}$ The Tax protein is required for rep- 
Table 1 Diseases associated with human T lymphotropic virus type 1 (HTLV-1) infection ${ }^{23}$

\begin{tabular}{ll}
\hline Disease & Refs \\
\hline Adult T cell leukaemia/lymphoma & 10,11 \\
HTLV-1 associated myelopathy/tropical spastic & \\
paraparesis & $24,25,26$ \\
Polymyositis & 27 \\
Arthropathy & 28 \\
Infective dermatitis & 29 \\
Uveitis & 30 \\
\end{tabular}

lication of the virus. It is also strongly implicated in the leukaemogenesis that leads to ATL, ${ }^{18}{ }^{19}$ and it is the chief target antigen recognised by the strong cytotoxic $\mathrm{T}$ lymphocyte response to the virus. As well as activating the transcription of HTLV-1 genes, Tax also induces expression of many cellular genes, including those encoding interleukin 2 (IL-2), the IL-2 receptor, granulocytemacrophage colony stimulating factor, tumour necrosis factor $\alpha$, and others. ${ }^{17}{ }^{19}$ An understanding of the Tax protein is therefore essential for an understanding of the biology of the virus and its associated diseases.

The host cell infected by HTLV-1 is the CD4 positive $\mathrm{T}$ cell ( $\mathrm{T}$ helper cell). Many other human cell types can be infected in vitro, but appreciable productive replication occurs only in the CD4 positive $\mathrm{T}$ cell. The cellular receptor for the virus has been mapped to chromosome $17,{ }^{20}$ but has not yet been identified. Intercellular adhesion molecule 1 (ICAM-1), ICAM-3, and vascular cell adhesion molecule also facilitate entry of HTLV-1 into the cell, but are not the main receptors for the virus. ${ }^{21}{ }^{22}$

Diseases associated with HTLV-1 (table 1) ADULT T CELL LEUKAEMIA/LYMPHOMA (ATL)

The clinical features of ATL ${ }^{11}$ are those of a non-Hodgkin's lymphoma: malaise, fever, lymphadenopathy, hepatosplenomegaly, jaundice, drowsiness, weight loss, and opportunistic infections. Other features particularly associated with ATL are thirst and skin involvement (nodules, plaques, or a generalised papular rash). The transformed $\mathrm{T}$ cell has a characteristic appearance: the nucleus has multiple lobules, ${ }^{31}$ giving rise to the epithet "flower cells". Laboratory findings often include hypercalcaemia (which causes the thirst) and high serum concentrations of lactate dehydrogenase and the soluble IL- 2 receptor $\alpha$ chain. The leukaemic cells are almost invariably CD4 positive, and are usually CD25 positive (IL-2 receptor $\alpha$ positive).

ATL is classified into clinical subtypes with different courses and prognoses (table 2). ${ }^{31-33}$ Southern blot analysis indicates the presence of oligoclonal or monoclonal proliferation of CD4 positive cells that carry the HTLV-1 provirus in the cellular DNA. ${ }^{16}$ Typically there is a progression from polyclonal to oligoclonal to monoclonal proliferation in vivo, accompanied by a progression to increasing IL-2 independence of cellular growth. ${ }^{16} 1834$

The lifetime risk of ATL is about $5 \%$ in people infected before the age of 20 years ${ }^{35}$; the incidence is approximately $0.1 \%$ infected
Table 2 Relative incidence of different subtypes of adult $T$ cell leukaemiallymphoma, and their prognoses ${ }^{3 t-33}$

\begin{tabular}{llll}
\hline Subtype & \% Total & $\begin{array}{l}\text { Median survival } \\
\text { (months) }\end{array}$ & $\begin{array}{l}\text { Five year } \\
\text { survival }\end{array}$ \\
\hline Acute & 55 & 6.2 & $5.0 \%$ \\
Lymphomatous & 20 & 10.2 & $5.7 \%$ \\
Chronic & 20 & 24.3 & $26.9 \%$ \\
Smouldering & 5 & - & $62.8 \%$ \\
\hline
\end{tabular}

individuals/year. There is a wide disparity in the mean age at diagnosis: 60 years in Japan, but 40 years in the Caribbean and Brazil; the reason for this disparity is unknown. ${ }^{35-37}$ Men are more commonly affected than women ${ }^{36}$ (approximately 1.5:1 male to female ratio).

The disease often responds initially to standard chemotherapeutic regimens, but early relapse is common, and the disease typically becomes refractory to further chemotherapy after two to six months. Recently, considerable progress has been made with the discovery that a combination of interferon $\alpha$ and AZT (zidovudine) can prolong life expectancy by between six months and two years. ${ }^{38-40}$ However, fundamental improvements in the management of this aggressive condition are needed.

HTLV-1 ASSOCIATED MYELOPATHY/TROPICAL SPASTIC PARAPARESIS

In the mid 1980s a French group in Martinique discovered ${ }^{24}$ an association between HTLV-1 seropositivity and chronic progressive myelopathy of previously unknown aetiology, known as Jamaican neuropathy or tropical spastic paraparesis. ${ }^{25}$ An association with a similar disease was described in Japan by Osame and his colleagues, ${ }^{26}$ who called the disease HTLV-1 associated myelopathy; subsequently it was established that these are the same condition, ${ }^{41}$ and it is now generally referred to as HAM/TSP.

HAM/TSP typically develops ${ }^{23}$ in a woman in her forties as a progressive spastic weakness of the legs, usually associated with low back pain, urinary frequency or incontinence, and paraesthesiae in the legs. The course is variable: most patients progress over six months to two years, but in some the disease activity appears to continue indefinitely. The final state also varies between the ability to walk with one stick and being bed bound with painful spasms and contractures.

The lifetime risk of HAM/TSP is about $1-2 \%{ }^{42}$; estimates of the prevalence vary between $0.1 \%$ and $2 \%$ of infected individuals, rising sharply with age. The mean age at onset of HAM/TSP is about 40 years, and women are affected twice or three times more often than men. There are well documented cases in which HAM/TSP develops within months of infection by contaminated blood products ${ }^{43}$; this contrasts strongly with ATL, which usually develops after an incubation period of decades. ${ }^{37}$ ATL and HAM/TSP can occur together, ${ }^{44}{ }^{45}$ but no more frequently than would be expected as a result of chance.

Unlike ATL, HAM/TSP is not usually a fatal condition, although a precise estimate has not been made of the effect of HAM/TSP on life expectancy. The mean duration of disease at 


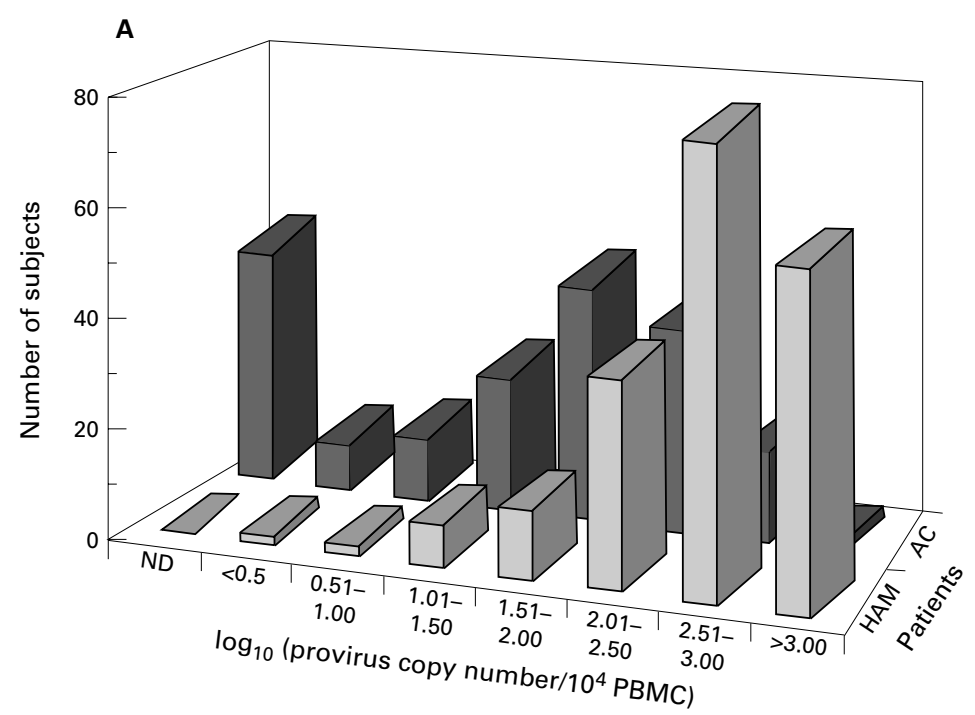

B

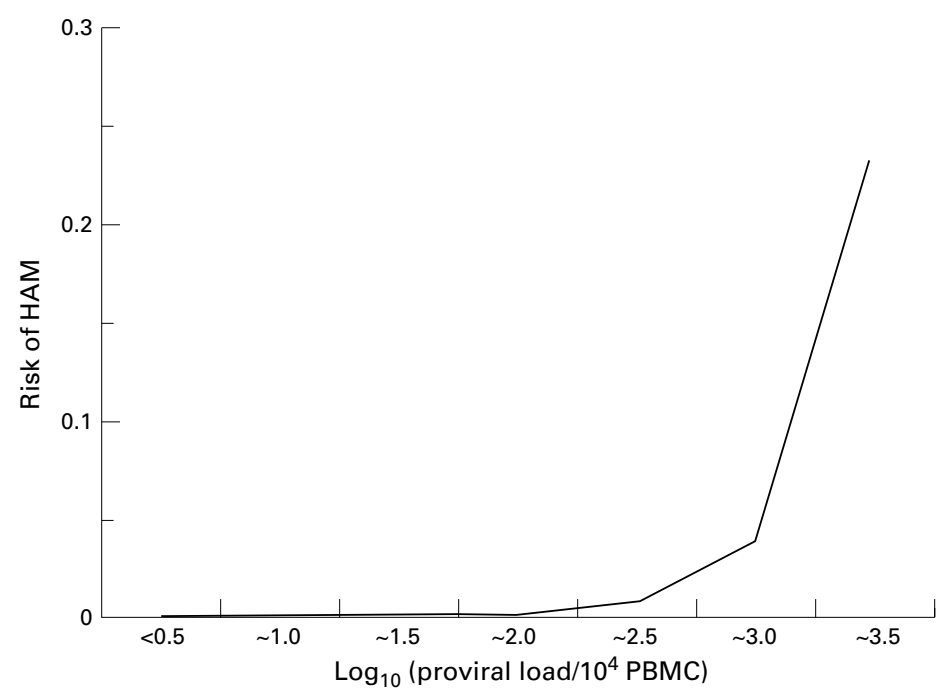

Figure 1 (A) Distribution of human T lymphotropic virus type 1 (HTLV-1) proviral load in 202 patients with tropical spastic paraparesis (HAM/TSP) and 200 asymptomatic carriers of HTLV-1 (AC) in Kagoshima, southern fapan. ${ }^{56}$ The lower limit of detection was one provirus copy $/ 10^{4}$ peripheral blood mononuclear cells (PBMCs). ${ }^{56}$ The median proviral load in patients with HAM/TSP was 16 times greater than in asymptomatic carriers. ND, not determined. (B) The risk of HAM/TSP depends on the proviral load of HTLV-1. The vertical axis shows the risk of HAM/TSP at a given $\log _{10}$ (HTLV-1 proviral load). The risk remains very low until the proviral load reaches $1 \%$ PBMCs; above this apparent threshold, the risk of disease rises rapidly with increasing load. The prevalence of HAM/TSP among the seropositive adult population was assumed to be $0.01 .{ }^{5}$

death is about 10 years ${ }^{24}{ }^{46}$; death is usually attributed to infections or tumours.

On examination, the patient often has muscle weakness, hyperreflexia, and clonus in the lower limbs, and extensive plantar responsive and a spastic gait. The cerebrospinal fluid shows a mild pleocytosis, HTLV-1 antibodies, and a mild to moderate increase in protein concentration. ${ }^{23}$ The main neuropathological features of $\mathrm{HAM} / \mathrm{TSP}^{47}{ }^{48}$ are scattered lesions of diffuse demyelination in the cerebrum and (particularly) the lower cervical and upper thoracic spinal cord, and a widespread mononuclear cell infiltrate with perivascular cuffing and parenchymal invasion associated with these demyelinated areas.

There is no treatment of proved value in HAM/TSP. Drugs used in informal therapeutic trials have included corticosteroids, anabolic steroids, zidovudine (AZT), and vitamin C, ${ }^{49-51}$ but none gave lasting benefit. Recently, Taylor and colleagues ${ }^{52}$ have obtained evidence that lamivudine (3TC) (150 mg twice daily) can reduce the provirus load of HTLV-1. Again, the effects-symptomatic improvement and reduction in provirus load-were temporary, but it is possible that drug regimens that produce a more sustained reduction in proviral load will provide some benefit, particularly if started early in the course of clinical disease. These exciting preliminary findings are shortly to be tested in a randomised, placebo controlled trial.

OTHER DISEASES ASSOCIATED WITH HTLV-1

In addition to ATL and HAM/TSP, HTLV-1 has been associated with a range of chronic or subacute inflammatory conditions in different tissues (table 1). ${ }^{17}{ }^{23}$ These associations are weaker than those with ATL and HAM/TSP, and it is not yet agreed that HTLV-1 is the likely cause in each condition.

\section{The proviral load of HTLV-1}

The proviral load of HTLV-1 is unusually high compared with other retrovirus infections: a typical healthy carrier of HTLV-1 carries the provirus in about $0.1-1 \%$ of peripheral blood mononuclear cells (PBMCs). However, the provirus load is, on average, even higher in the chronic inflammatory diseases such as HAM/ TSP, ranging up to $30 \%$ of PBMCs. ${ }^{53-56}$ The proviral load appears to be stable over many years in most individuals. In a recent case control study in Japan, we found ${ }^{56}$ that the prevalence of HAM/TSP rises very sharply once the proviral load exceeds $1 \%$ of PBMCs (fig 1).

This association between HAM/TSP and a high proviral load of HTLV-1 has been recognised for several years, and it is widely believed that healthy carriers of HTLV-1 with a high proviral load carry a high risk of progression to disease. Preliminary data from an eight year prospective cohort follow up study of healthy HTLV-1 carriers are consistent with this view, ${ }^{58}$ but large scale, long term studies are needed to reach a definitive conclusion.

These observations suggest that a high proviral load plays an important part in the aetiology of the inflammatory diseases. The two main questions that arise are: (1) What determines the proviral load "set point" in each individual? In particular, does the immune response play an important role? (2) How does a high proviral load cause HAM/TSP and the related conditions? Because there appears to be no neuropathic strain of HTLV- $1,{ }^{59}$ the different disease manifestations of HTLV-1 infection must be attributable to differences in host susceptibility or resistance to the virus. Therefore, to answer these questions we must first understand something of the immune response to HTLV-1.

\section{Immune response to HTLV-1}

Antibodies against the Gag protein of HTLV-1 (mainly p24) are the first to appear after infec- 
tion, and predominate in the first two months, followed by anti-Env antibodies. ${ }^{61}$ About $50 \%$ of individuals subsequently produce antibodies to the Tax protein. ${ }^{2}$

The cellular immune response has not been studied systematically in the early stages of infection with HTLV-1. However, in the chronic phase, most infected individuals make a very strong cell mediated immune response to the virus. ${ }^{57}$ The cytotoxic $\mathrm{T}$ lymphocyte (CTL) response to HTLV-1 has been studied in particular detail, because animal experiments in many virus infections indicate the special importance of these cells in limiting viral replication. ${ }^{62}$ In addition, the mononuclear cell infiltrate found in the spinal cord in the areas of demyelination consists predominantly of $\mathrm{T}$ cells, which are mainly CD8 positive (the usual phenotype of antiviral CTLs), at least in the chronic phase. ${ }^{47} 4863$

Anti-HTLV-1 CTLs are unusual in their extreme abundance: up to $10 \%$ of circulating CD8 positive $T$ cells can recognise just one epitope of the virus. ${ }^{64-66}$ The anti-HTLV-1 CTLs are unusual in two further respects: they are chronically activated, and most recognise a single viral protein, the Tax protein. ${ }^{57}$ How does the virus persist in the face of such a strong immune response? Specifically, do mutations in the Tax protein lead to escape from recognition by CTLs? Putative CTL escape mutations in Tax were indeed identified by Niewiesk et al. ${ }^{67}$ However, the selection pressure on the tax gene, presumably exerted by the Tax specific CTLs, was only evident in the healthy carriers of the virus, not in the patients with HAM/TSP. ${ }^{68}{ }^{69}$ We concluded $^{6070}$ that the HTLV-1 specific CTLs might play an important part in limiting the replication of the virus, so determining the individual's proviral load of HTLV-1 and their risk of inflammatory diseases such as HAM/TSP.

\section{HLA-A ${ }^{\star} 02$ protects against HTLV-1 associated myelopathy}

This conclusion suggested in turn ${ }^{60}$ that individual variation in the "efficiency" or "strength" of the anti-HTLV-1 CTL response might explain why some HTLV-1 infected people develop a high proviral load and diseases such as HAM/TSP, whereas others effectively suppress the replication of HTLV-1 and remain healthy. To test this hypothesis, we have compared the frequencies of polymorphic candidate genes between asymptomatic carriers and patients with HAM/TSP in Kagoshima (in southern Japan) in collaboration with Professor M Osame. This study has produced a clear result: patients who carry the human major histocompatibility complex (HLA) allele, HLA-A ${ }^{\star} 02$ (HLA-A2) have only half the risk of developing HAM/TSP as those who lack this allele. ${ }^{6}$ Because HLA class I genes are known to determine the specificity of CTLs, this observation suggests that HLA-A ${ }^{\star} 02$ restricted CTLs are particularly efficient at controlling HTLV-1 replication, and strongly supports the hypothesis ${ }^{60}$ that the CTL response to the virus is an important determinant of the risk of disease. In further support of this conclusion, healthy carriers of HTLV-1 who possessed the HLA-A ${ }^{\star} 02$ allele had a significantly lower proviral load of HTLV-1 than those who lacked this allele. ${ }^{66}$

Because HLA-A ${ }^{\star} 02$ is common in $\mathrm{Ka}$ goshima, as in all major human populations, its protective effect is very important at the population level: the presence of HLA-A ${ }^{\star} 02$ at its observed frequency prevents approximately $28 \%$ of potential cases of HAM/TSP in Kagoshima. ${ }^{66}$

The results of this study also confirmed previous indications ${ }^{71} 72$ that the class II HLA gene, HLA-DRB $1{ }^{\star} 0101$ (HLA-DR1) appears to increase the risk of HAM/TSP; the reason for this association is not yet explained. However, the predisposing effect of HLA$\mathrm{DRB} 1^{\star} 0101$ is seen only in people who lack HLA-A ${ }^{\star} 02$. That is, the HLA-A ${ }^{\star} 02$ associated protection appears to be dominant. ${ }^{66}$

Many HLA disease associations have been described. However, in most cases the HLA allele is associated with predisposition to disease, not with protection, and the reason for the association is not clear. The association of HLA-A ${ }^{\star} 02$ with protection from HAM/TSP is, by contrast, the only clear example of protection against any viral disease by a single class I HLA gene; and the reason for the association-efficient CTL surveillance against the virus - immediately suggests itself.

The protective effect of HLA-A ${ }^{\star} 02$ also has direct implications for vaccination against both HIV $-1^{73}$ and HTLV- ${ }^{1}$ : it implies that an effective antiretroviral vaccine will elicit a strong and persistent CTL response to the virus.

\section{Pathogenesis of HAM/TSP}

The recent results, summarised above, cast light on the reasons for individual variation in disease risk in HTLV-1 infection. However, the mechanism of pathogenesis of HAM/TSP and the other inflammatory diseases remains a matter for speculation. By exclusion of other possibilities, we and others have suggested ${ }^{576075} 76$ that the tissue damage in the central nervous system (CNS) is caused by lymphocytes, chronically activated by the HTLV-1 Tax protein acting as an antigen and/or a mitogen, which migrate into the CNS as a result of the Tax induced upregulation of adhesion molecules on their surface. HTLV-1 infected or activated lymphocytes have indeed been shown to secrete large amounts of certain cytokines and metalloproteinases, ${ }^{77}$ which might be toxic in high local concentrations in the CNS. However, it must be emphasised that this is a speculative scheme at present. It is to be hoped that the results of further genetic studies on the risk of HAM/TSP will suggest pathways of pathogenesis that can be subjected to experimental testing.

\section{HTLV-1 is a highly dynamic infection}

Because of the relative constancy of the HTLV-1 genome sequence, and the difficulty in detecting HTLV-1 proteins in freshly isolated blood cells, it has been generally believed that the virus is largely latent; that is, 


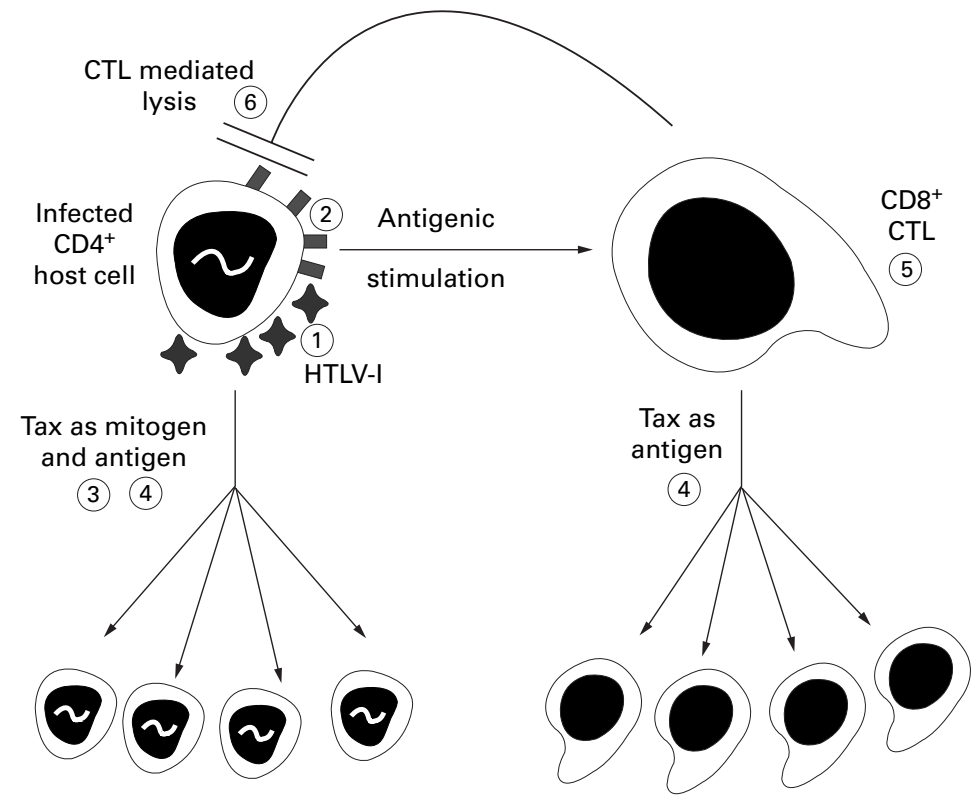

Proliferating $\mathrm{CD}^{+}$help to maintain the high provirus load
The peripheral blood contains abundant chronically activated CTL specific to HTLV-I

Figure 2 Human Tlymphotropic virus type 1 (HTLV-1) infection establishes a dynamic equilibrium between virus replication and immune destruction. The infected CD4 positive host cell produces new HTLV-1 virus particles (1), and HTLV-1 derived antigenic peptides complexed with class I and class II human major histocompatibility complex (HLA) proteins on its surface (2). The HTLV-1 virions infect susceptible neighbouring CD 4 positive cells. The Tax protein of HTLV-1 acts both as mitogen and antigen, to drive the division of infected CD4 positive and CD8 positive $T$ cells that are specific for Tax (4). The stimulated CD8 positive cytotoxic T cells (CTLs) recognise and kill host cells that express HTLV-1 Tax-HLA protein complexes on the cell surface (5). Tax is not the only HTLV-1 antigen recognised by lymphocytes, but it has a position of special importance because it is the first HTLV-1 protein to be produced, and is a powerful mitogen and antigen.

transcriptionally silent. However, the highly active CTL response and the evidence of positive selection on Tax suggest ${ }^{78}$ that the virus is in fact constantly transcribing its genome in an attempt to make complete $\mathrm{HTLV}-1$ virions. The emerging picture is one of a highly dynamic equilibrium between the virus and the immune system (fig 2). Intuition is a poor guide to understanding this equilibrium, because of the complexity of the positive and negative feedback mechanisms involved. Mathematics is therefore essential to ensure rigour in the reasoning: it cannot prove that a biological conclusion is correct, but it can prove that the conclusion does not follow from the assumptions. In this way mathematical reasoning has an important part to play in understanding the dynamics of viral infections such as HTLV-1..$^{70} 78$

\section{Conclusion}

Important questions remain in addition to that of the pathogenesis of HAM/TSP. The HLA$\mathrm{A}^{\star} 02$ allele provides only partial protection against the disease: what other factors are involved? Are other polymorphic genes responsible? Does HLA-A ${ }^{\star} 02$ also protect against ATL? How does HLA-DRB ${ }^{\star} 0101$ predispose to disease? How can we devise a safe vaccine that elicits a persistent, specific CTL response?

The answers to these questions will come not from work in a single discipline, but from results in immunology, virology, population genetics, neuropathology, and mathematics.

The lessons learned will throw light on many other persistent virus infections, including HIV-1, hepatitis B, and hepatitis C.

I thank my colleagues for stimulating discussions, and the Wellcome Trust and the Medical Research Council for support of this research.

1 de The G, Bomford R. An HTLV-I vaccine: why, how, for whom? AIDS Res Hum Retroviruses 1993; 9:381-6.

2 Mueller NE, Blattner WA. Retroviruses: HTLV. In: Evans AS, Kaslow R, eds. Viral infections of humans: epidemiology and control, 4th ed. New York: Plenum Medical Press, 1996.

3 Stuver SO, Tachibana N, Okayama A, et al. Heterosexual transmission of human $\mathrm{T}$ cell leukaemia/lymphoma virus type 1 among married couples in southwestern Japan: an initial report from the Miyazaki cohort study. F Infect Dis 1993;167:57-65

4 Okochi K, Sato H, Hinuma Y. A retrospective study on transmission of adult T-cell leukaemia virus by blood transfusion: seroconversion in recipients. Vox Sang 1984; 46:245-53.

5 Manns A, Wilks RJ, Murphy EL, et al. A prospective study of transmission by transfusion of HTLV-1 and risk factors associated with seroconversion. Int $\mathcal{F}$ Cancer 1992;51:88691.

6 Kamihira S, Naskasima S, Oyakawa Y, et al. Transmission of human $\mathrm{T}$ cell lymphotropic virus type I by blood transfusion before and after mass screening of sera from seropositive donors. Vox Sang 1987;52:43-4.

7 Hino S, Katamine S, Miyata H, et al. Primary prevention of HTLV-1 in Japan. Leukaemia 1997;11(suppl 3):57-9.

8 Licensure of screening tests for antibody to human $\mathrm{T}$ -lymphotropic virus type I. MMWR Morb Mortal Wkly Rep 1988;37:736-47.

9 Heredia A, Soriano V, Weiss SH, et al. Development of a multiplex PCR assay for the simultaneous detection and discrimination of HIV-1, HIV-2, HTLV-1 and HTLV-II. Clin Diagn Virol 1997; 7:85-92.

10 Poiesz BJ, Ruscetti FW, Gazdar AF, et al. Detection and isolation of type c retrovirus particles from fresh and cultured lymphocytes of a patient with cutaneous T-cell lymphoma. Proc Natl Acad Sci US A 1980;77:7415-19.

11 Uchiyama T, Yodoi J, Sagawa K, et al. Adult T-cell leukaemia: clinical and haematological features of 16 cases. leukaemia: clinical and

12 Hinuma Y, Nagata K, Hanaoka M, et al. Adult T-cell leukaemia: antigen in an ATL cell line and detection of antibodies to the antigen in human sera. Proc Natl Acad Sci US A 1981;78:6476-80.

13 Blattner WA, Kalyanaraman VS, Robert GM, et al. The human type-C retrovirus, HTLV, in Blacks from the Caribbean region, and relationship to adult T-cell leukaemia/ lymphoma. Int f Cancer 1982;30:257-64.

14 Hinuma Y, Komoda H, Chosa T, et al. Antibodies to adult T-cell leukaemia-virus-associated antigen (ATLA) in sera from patients with ATL and controls in Japan: a nation-wide sero-epidemiologic study. Int $\mathcal{F}$ Cancer 1982; 29:631-5.

15 Yoshida M, Miyoshi I, Hinuma Y. Isolation and characterization of retrovirus from cell lines of human adult T-cell leukaemia and its implication in the disease. Proc Natl Acad Sci U S A 1982;79:2031-5.

16 Yoshida $M$, Seiki M, Yamaguchi $\mathrm{K}$, et al. Monoclonal integration of human T-cell leukemia provirus in all primary tumours of adult T-cell leukemia suggests causative role of human T-cell leukaemia virus in the disease. Proc Natl Acad Sci U S A 1984;81:2534-7.

17 Cann AJ, Chen ISY. Human T-cell leukemia virus types I and II. In: Fields BN, Knipe DM, Howley PM, et al, eds. Fields virology, Vol. 59. Philadelphia: Raven Publishers, 1996:1849-80.

18 Franchini G. Molecular mechanisms of human T-cell leukaemia/lymphotropic virus type I infection. Blood 1995; 86:3619-39.

19 Uchiyama T. Human $\mathrm{T}$ cell leukaemia virus type 1 (HTLV-I) and HTLV-I-associated diseases. Annu Rev Immunol 1997;15:15-37.

20 Sommerfelt MA, Williams BP, Clapham PR, et al. Human T cell leukaemia viruses use a receptor determined by human cell leukaemia viruses use a receptor detern
chromosome 17. Science 1988;242:1557-9.

21 Hildreth JEK, Subramanium A, Hampton RA. Human T-cell lymphotropic virus type 1 (HTLV-1)-induced syncytium formation mediated by vascular cell adhesion molecule-1: evidence for involvement of cell adhesion molecules in HTLV-1 biology. F Virol 1997;71:1173-80.

22 Daenke S, McCracken SA, Booth S. Human T-cell leukaemia/lymphoma virus type 1 syncytium formation is regulated in a cell-specific manner by ICAM-1, ICAM-3 and VCAM-1 and can be inhibited by antibodies to integrin beta2 or beta7. F Gen Virol 1999;80:1429-36.

23 Nakagawa M, Izumo S, Ijichi S, et al. HTLV-I-associated myelopathy: analysis of 213 patients based on clinical features and laboratory findings. F Neurovirol 1995;1:50-

24 Gessain, A, Barin F, Vernant JC, et al. Antibodies to human T-lymphotropic virus type I in patients with tropical spastic paraparesis. Lancet 1985;2:407-10.

25 Cruickshank EK. A neuropathic syndrome of uncertain origin. West Indian Med f 1956;5:147-58. 
26 Osame M, Usuku K, Izumo S, et al. HTLV-I-associated myelopathy: a new clinical entity. Lancet 1986;1:1031-2. 7 Morgan OStC, Rodgers-Johnson P, Mora C, et al. HTLV-I and polymyositis in Jamaica. Lancet 1989;2:1184-7.5]

28 Nishioka K, Maruyama I, Sato K, et al. Chronic inflammatory arthropathy associated with HTLV-I. Lancet 1989;1 441

29 LaGrenade L, Hanchard B, Fletcher V, et al. Infective dermatitis of Jamaican children: a marker for HTLV-I infection. Lancet 1990;336:1345-7.

30 Mochizuki M, Watanabe T, Yamaguchi K, et al. HTLV-I uveitis: a distinct clinical entity caused by HTLV-I. $7 p n n^{f}$ Cancer Res 1992;83:236-9.

31 Shimoyama M. Diagnostic criteria and classification of clinical subtype of adult T-cell leukaemia-lymphoma. A report from the lymphoma study group (1984-1987). Br F Haematol 1991;79:428-37.

32 Yamaguchi K, Takatsuki K. A proposal for smoldering adult T-cell leukaemia: a clinicopathology study of five cases. Blood 1983;62:758-66.

33 Kawano F, Yamaguchi K, Nishimura $\mathrm{H}$, et al. Variation in the clinical course of adult T-cell leukemia. Cancer 1985;55:851-6.

34 Hollsberg P, Wucherpfennig K, Ausubel LJ, et al. Characterization of HTLV-I in vivo infected T cell clones. IL-2 independent growth of non-transformed T cells. F Immunol 1992;148:3256

35 Cleghorn FR, Manns A, Falk R, et al. Effect of human T-lymphotropic virus type I infection on non-Hodgkin's lymphoma incidence. 7 Natl Cancer Inst 1995;87:1009-14.

36 Kondo T, Kono H, Miyamoto N, et al. Age-and sex-specific cumulative rate and risk of ATLL for HTLV-1 carriers. Int 7 Cancer 1989;43:1061-4.

37 Tajima K. The 4th nation-wide study of adult T-cell leukaemia/lymphoma (ATL) in Japan: estimates of risk of ATL and its geographical and clinical features. The T-cell and B-cell malignancy study group. Int 7 Cancer 1990;45: 237-43.

38 Gill PS, Harrington W, Kaplan M, et al. Treatment of adult T-cell leukaemia-lymphoma with a combination of inter-

39 Hermine O, Bouscary D, Gessain A, et al. Brief report: treatment for adult T-cell leukaemia-lymphoma with zidovudine and interferon alfa. N Engl f Med 1995; 332:174951.

40 Wharfe G, Hanchard B. Zidovudine and interferon therapy for adult T-cell leukaemia/lymphoma: results of a preliminary study at UHWI-Mona. West Indian Med f 1996;45: $107-9$.

41 Report from the scientific group on HTLV-1 infection and its associated diseases, convened by the regional office for the Western Pacific of the World Health Organisation in Kagoshima, Japan, 10-15 December 1988. Wkly Epidemiol $\operatorname{Rec} 1989 ; 49: 382-3$.

42 Maloney EM, Cleghorn FR, Morgan OS, et al. Incidence of HTLV-1 associated myelopathy/tropical spastic paraparesis (HAM/TSP) in Jamaica and Trinidad. 7 Acquir Immune Defic Syndr Hum Retrovirol 1998;17:167-70.

43 Gout O, Baulac M, Gessain A, et al. Rapid development of myelopathy after HTLV-1 infection acquired by transfumyelopathy after HTLV-1 infection acquired by transfusion during cardiac

44 Kawai H, Nishida Y, Takagi M, et al. HTLV-1-associated myelopathy with adult T-cell leukaemia. Neurology 1989 39:1129-31

45 Tamiya S, Matsuoka M, Takemoto S, et al. Adult T-cell leukaemia following HTLV-1-associated myelopathy/tropical spastic paraparesis: case reports and implication to the natural course of ATL. Leukaemia 1995;9:768-70.

46 Osame M, Jassen R, Kubota $\mathrm{H}$, et al. Nationwide survey of HTLV-1-associated myelopathy in Japan: association with blood transfusion. Ann Neurol 1990;28:50-6.

47 Iwasaki Y. Human T-cell leukemia virus type-1 infection and chronic myelopathy. Brain Pathol 1993;3:1-10.

48 Umehara F, Izumo S, Nakagawa $M$, et al. Immunocytochemical analysis of the cellular infiltrate in the spinal cord lesions in HTLV-I-associated myelopathy. 7 Neuropathol Exp Neurol 1993;52:424-30.

49 Gout O, Gessain A, Iba-Zizen M, Kouzan S, et al. The effect of zidovudine on chronic myelopathy associated with of zidovudine on chronic myelo

50 Harrington WJ, Sheramata WA, Snodgrass SR, et al. Tropical spastic paraparesis/HTLV-1-associated myelopathy (TSP/HAM): treatment with an anabolic steroid Danazol. AIDS Res Hum Retroviruses 1991;7:1031-4.

51 Kataoka A, Imai H, Inayoshi S, et al. Intermittent high-dose vitamin C therapy in patients with HTLV-1 associated myelopathy. F Neurol Neurosurg Psychiatry 1993;56:1213.

52 Taylor GP, Hall SE, Navarrete S, et al. Effect of lamivudine on HTLV-I DNA copy number, T-cell phenotype and antiTax cytotoxic T-cell frequency in patients with HTLV-Iassociated myelopathy. $\mathcal{F}$ Virol 1999;73:10289-95.

53 Yoshida, $M$, Osame $M$, Kawai $\mathrm{H}$, et al. Increased replication of HTLV-I in HTLV-I-associated myelopathy. Ann Neurol 1989;26:331-5.
54 Gessain A, Saal F, Gout O, et al. High human T-cell ymphotropic virus type I proviral DNA load with polycloal integration in peripheral blood mononuclear cells of French West Indian, Guianese, and African patients with tropical spastic paraparesis. Blood 1990;75:428-33.

55 Kira J, Koyanagi Y, Yamada T, et al. Increased HTLV-I proviral DNA in HTLV-I-associated myelopathy: a quantitative polymerase chain reaction study. Ann Neurol 1991;29: 194-201

56 Nagai M, Usuku K, Matsumoto W, et al. Analysis of HTLV-I proviral load in $202 \mathrm{HAM} / \mathrm{TSP}$ patients and 243 asymptomatic HTLV-I carriers: high proviral load strongly predisposes to HAM/TSP. $\mathcal{F}$ Neurovirol 1998;4:586-93.

57 Bangham, CRM, Hall SE, Jeffery KJM, et al. Genetic control and dynamics of the cellular immune response to the human T-cell leukaemia virus HTLV-I. Philos Trans $R$ Soc Lond Ser B Biol Sci 1999;354:691-700.

58 Taylor GP, Tosswill JHC, Matutes E, et al. A prospective study of HTLV-I infection in an initially asymptomatic cohort. F Acquir Immune Defic Syndr 2000;22:92-100.

59 Daenke S, Nightingale S, Cruickshank JK et al. Sequence variants of human T-cell lymphotropic virus type I from patients with tropical spastic paraparesis and adult T-cell eukemia do not distinguish neurological from leukemic isolates. $\mathcal{F}$ Virol 1990;64:1278-82.

60 Bangham CRM, Kermode AG, Hall SE, et al. The cytotoxic T-lymphocyte response to HTLV-I: the main determinant of disease? Semin Virol 1996;7:41-8.

61 Manns A, Murphy EL, Wilks R, et al. Detection of early human T-cell lymphotropic virus type I antibody patterns during seroconversion among transfusion recipients. Blood 1991;77:896-905.

62 McMichael AJ. Immunology. In: Weatherall DJ, Ledingham JGG, Warrell DA, eds. Oxford textbook of medicine, 3rd ed. JGG, Warrell DA, eds. Oxford textbook of medicine,

63 Moore GRW, Traugott U, Scheinberg LC, et al. Tropical spastic paraparesis: a model of virus-induced cytotoxic T-cell-mediated destruction? Ann Neurol 1989;26:523-30.

64 Elovaara I, Koenig S, Brewah AY, et al. High human T cell lymphotropic virus type 1 (HTLV-1)-specific precursor cytotoxic $T$ lymphocyte frequencies in patients with HTLV-1-associated neurological disease. f Exp Med 1993; 177:1567-73

65 Daenke S, Kermode AG, Hall SE, et al. High activated and memory cytotoxic T-cell responses to HTLV-I in healthy carriers and patients with tropical spastic paraparesis. Virol 1996;217:139-46.

66 Jeffery KJM, Usuku K, Matsumoto W, et al. HLA alleles determine human T-lymphotropic virus-I (HTLV-I) proviral load and the risk of HTLV-I-associated myelopathy. Proc ral load and the risk of HTLV-I-associated

67 Niewiesk S, Daenke S, Parker CE, et al. Naturally occurring variants of HTLV-I Tax protein impair its recognition by CTL and the transactivation function of Tax. F Virol 1995; 69:2649-53

68 Niewiesk S, Bangham CRM. Evolution in a chronic RNA virus infection: selection on HTLV-I Tax protein differs between healthy carriers and patients with tropical spastic paraparesis. F Mol Evol 1996;42:452-8.

69 Niewiesk S, Daenke S, Parker CE, et al. The transactivator gene of human T-cell leukemia virus type I is more variable within and between healthy carriers than patients with tropical spastic paraparesis. F Virol 1994;68:6778-81.

70 Nowak MA, Bangham CRM. The population dynamics of immune responses to persistent virus infections. Science 1996;272:74-9.

71 Usuku K, Sonoda S, Osame M, et al. HLA haplotype-linked high immune responsiveness against HTLV-I in HTLV-Iassociated myelopathy: comparison with adult T-cell leukemia/lymphoma. Ann Neurol 1988;23(suppl):S143-50.

2 Usuku K, Nishizawa M, Matsuki K, et al. Association of a particular amino acid sequence of the HLA DR beta1 chain with HTLV-I-associated myelopathy. Eur f Immunol 1990;20:1603-6.

73 Paul WE. Can the immune response control HIV infection? Cell 1995;82:177-82

74 Bangham CRM, Phillips RE. What is required of an HIV vaccine? Lancet 1997;350:1613-17.

75 Daenke S, Bangham CRM. Do T cells cause HTLV-Iassociated disease? A taxing problem. Clin Exp Immunol 1994:96:179-81.

76 Ijichi S, Izumo S, Eiraku N, et al. An autoaggressive process against bystander tissues in HTLV-I-infected individuals: a possible pathomechanism of HAM/TSP. Med Hypotheses 1993;41:542-7

77 Biddison W, Kubota R, Kawanishi T, et al. Human T cell leukemia virus type I (HTLV-I)-specific CD8+ CTL clones from patients with HTLV-I-associated neurologic disease secrete proinflammatory cytokines, chemokines, and matrix metalloproteinase. F Immunol 1997;159:2018-

78 Wodarz D, Nowak MA, Bangham CRM. The dynamics of HTLV-I and the CTL response. Immunol Today 1999;20: $220-7$. 